\title{
The institutionalization of Brazilian Political Thought in the Social Sciences: Wanderley Guilherme dos Santos' Research Revisited (1963-1978)
}

\author{
Christian Edward Cyril Lynch \\ Institute of Political and Social Studies, State University of Rio de Janeiro \\ (IESP/UERJ), Brazil
}

In this article I shall analyze the content of Wanderley Guilherme dos Santos' research, carried out between the decades of 1960 and 1970, and in the end perform an assessment of his contribution to the studies of Brazilian political thought. In summary, from his research there emerged a thesis for the existence of a national political culture; that Brazilian political thought was its intellectual product par excellence and that it would not be possible to comprehend the rugged Brazilian political process without studying this phenomenon.

Keywords: Wanderley Guilherme dos Santos; Brazilian political thought; political science.

\section{Introduction}

W anderley Guilherme dos Santos' research on Brazilian political thought began in 1963 when he was head of the philosophy department at the Higher Institute of Brazilian Studies (ISEB). It originated from a request by Álvaro Vieira Pinto, his former professor at the National Faculty of Philosophy and head of the institute at the time. Vieira Pinto intended to address the shortage of bibliographic records that could be used as an adequate reference source, which would be able to expand the accepted canon of works representative of Brazilian philosophy. In the company of Carlos Estevam Martins, Wanderley Guilherme dedicated himself to reading works from the $18^{\text {th }}$ and $19^{\text {th }}$ century in the rare books section at the National Library and at the library of the Social Service of Commerce (SESC). As he gradually lost interest in the metaphysical themes 
within this literature, Wanderley discovered, as if casually, works by several authors who were listed as philosophers as well as others not included in this category, which versed on Brazil's society and politics in the $19^{\text {th }}$ century. Wanderley then began his "conversion" process towards the social sciences in detriment of a philosophical production (though not of philosophical themes, whether in epistemology or political theory, as evidenced by his production). Most likely, this ISEB period marks the moment of his discomfort towards the prevailing modes for analyzing Brazilian thought, a discomfort that when formalized as a theoretical problem lies in the origin of his articles concerning this issue. Within the ISEB there was barely any possibility to consider past Brazilian thought, since the colonial nature of such past was considered to be an impediment for any consistent and autonomous intellectual production.

It was also during his ISEB period that he came into contact with the works of Guerreiro Ramos on Brazilian political thought, such as Efforts in theorizing Brazilian reality; The ideology of order; The ideology of jeunesse dorée; and The sociological subconscious. As we known, Guerreiro was the only professor at ISEB who called out to the fact that, in spite of a slow process of surmounting their "colonial" cultural condition, there was a lineage of Brazilian intellectuals who, ever since the $19^{\text {th }}$ century, stood out in the struggle for the autonomy of national thought and whose contributions should be redeemed in a context of establishing a Brazilian social science. In fact, contrary to the hegemonic perspective in the ISEB and in Guerreiro Ramos's argumentation, Wanderley Guilherme's initials readings at the National Library and SESC were an indication for him that not only was there originality in Brazilian thought prior to the 1950s, but also of the fact that the Isebian theses - considered to be original by members of the institute (especially by Hélio Jaguaribe) - had already been partially developed in works previously neglected by reason of their alleged compliance to a colonial mentality. ${ }^{1}$ The claim that a Brazilian intellectual elite existed and that their thought should be studied by those seeking to comprehend Brazil's contemporary dilemmas set up, from this period onwards, a research thesis and a horizon for Wanderley Guilherme on Brazilian political thought. And thus the gathering of such bibliographic material gave him motivation for more; he now wished to compile "as thoroughly as possible, the social, philosophical, and political Brazilian thought during

1 According to the author himself, this critique to the ISEB's self-image was the main content of his last course in that very own institution just before its closing due to the military dictatorship. The biographical information was retrieved from two main sources. The first is the interview listed as Appendix II in Marcelo Sevaybricker Moreira's master dissertation, The critical dialogue with polyarchic theory in Wanderley Guilherme dos Santos' political thought, defended in the Department of Political Science at UFMG in 2008. The second is the Memorial presented by Wanderley Guilherme to the Department of Social Sciences at IFCS in UFRJ in the year of 1993 for the occasion of the Exam for Head Professor of Political Science. 
the $19^{\text {th }}$ and $20^{\text {th }}$ centuries while also attempting to isolate some constants within Brazilian intellectual development" (Santos, 1965, p. 93).

The new research would begin in 1964 and was to last circa 2 years. With the military coup and ISEB being consequently shut down by the new regime, the regular research would only be resumed in the following year with the creation of the former Rio de Janeiro University Research Institute (IUPERJ, currently IESP-UERJ). The investigation would unfold until 1978 at least, being comprised of six articles or reference essays, which shall be object of analysis in this article. They are: 1) Preliminaries of a Sociological Controversy (1965); 2) Brazilian Sociopolitical Imagination (1967); 3) Bibliographical Roadmap for Brazilian Sociopolitical Thought (1967); 4) The Roots of Brazilian Political Imagination (1970); 5) Paradigm and History: the bourgeois order in the Brazilian social imagination (1978); 6) The Liberal Praxis in Brazil: proposals for reflection and research. (1978). I shall examine the content in each one of these texts so as to reflect on their contribution for the study of Brazilian political thought.

\section{Preliminaries of a Sociological Controversy (1965)}

The first result of the research was published in September 1965 in an article titled Preliminaries of a Sociological Controversy in the journal Revista Civilização Brasileira. The article argued against the political scientist Antônio Otávio Cintra, who had previously waged on a redirection in the Brazilian social sciences towards the North American empirical-quantitative paradigm. By aligning himself with a comprehensive sociology counter to positivism, Wanderley Guilherme argued in this first article that human and social facts did not only possess a brute and objective existence, just like natural phenomena, but they also incorporated meaning, conferring them with a decisively human character. For these reasons, the problem of elaborating a Brazilian social science was not reduced to acquiring modern investigative techniques; it had a historical connotation that was impossible to be ignored (Santos, 1965, p. 84). Even though he agreed with the need for more rigorous work methods, this should not reach a point where quantitative and qualitative techniques are opposite to one another. Besides, the opposition between a comprehensive and a generalizing sociology did not exhaust the alternatives in the social sciences. The elimination of dogmatic postulates seemed indispensable to him in order to "consider the science problem as a whole, and science in an underdeveloped country in particular" (Santos, 1965, p. 92). Brazilian intellectual production needed to be investigated without preconceived certainties not for antique inventory purposes or for an evolutionary prehistory of the Brazilian social sciences (as he believed Florestan Fernandes had done), but to "understand how truth emerges or begins to emerge from error itself" (Santos, 1965, p. 85). 
Considering that "Brazilian social thought" had not yet received any systematic treatment and that the ISEB methodological controversy was interrupted due to the closing of the institute in 1964, Wanderley called for a continuation of the research and presented in this article his first hypotheses and concepts on what he still called at the time the "history of ideas in Brazil". In his judgment, a preliminary reading of the examined material allowed him to detect that contrary to what was believed by the ISEB, the critical allegations concerning the Brazilian subordination to European formulations was not new: the debate surrounding the "problem of the subsidiary nature in Brazilian intellectual production" could already be found in a "larval stage" in the major debates of the $19^{\text {th }}$ century (Santos, 1965, p. 86). Even though the cultural alienation category was considered to be of some progress, Wanderley Guilherme argued that by separating alienated and "authentic" thought, the Isebians had confused name with concept and reduced alienated thought to the condition of erroneous thought, which did not seem reasonable to him. If in spite of the "alienated" theories, Brazil still managed to resolve decisive issues in its history - such as independence, abolishment of slavery, and industrialization - then there were two possibilities: either these theories were in tune to the Brazilian reality (which would contradict the hypothesis of alienation as a concept), or historical evolution occurred randomly to national conscience (which would contradict the Hegelian hypothesis that history holds a logic). Wanderley considered the first hypothesis to be correct: Brazilian intellectuals pragmatically arranged foreign intellectual products, "transfiguring their original meaning and adapting them to the country's prevailing conditions". The Hegelian cognitive apparatus - a prevailing characteristic in Brazilian academic analyses that used the alienation category - was unable to confer intelligibility to the real intellectual process (Marx himself, Santos argued, preferred to embrace the "praxis" category) (Santos, 1965, p. 94). Rather than "alienation", a more adequate concept to describe the process of assimilating foreign theories would be the concept of "mediation".

\section{Bibliographical Roadmap for Sociopolitical Brazilian Thought (1967)}

Assisted by a group of scholarship students, Wanderley Guilherme sought to define within the universe of Brazilian authors and works, those which could be listed as being constitutive of a "Brazilian sociopolitical thought". Starting from a research in books, periodicals, bibliographic bulletins and editorial archives, he and his team compiled an ample list of works considered to be social and political analyses between 1870 and 1965; a list that would only be published 35 years later: the Bibliographical Roadmap for Sociopolitical Brazilian Thought (Santos, 2002, p. 259-267). The list excluded texts devoted to methodology; those considered to be strictly historiographical, anthropological, economic, 
in the field of social psychology, and works dedicated to the exposition or criticism of specific authors (Santos, 2002, p. 13-14). Selected from a bibliographical research carried out within 45 bibliographic volumes and 23 collections of periodicals and bulletins, the impressive listing of three thousand texts is organized in two sections: in the first we find a list of articles published in periodicals; and in the second a list of books. The two lists are equally periodized spanning three moments in Brazilian political history: 1870-1930; 1931-1945; 1945-1965. The final chronological mark is clearly pragmatic: it coincides with the bibliographical research period (1965). However, there is no explicit justification for the initial starting point in the listing or in the articles published immediately before or afterwards.

However, an understanding of the choices behind these temporal milestones is relevant insofar as it clarifies what Wanderley considered to be not only the par excellence period for Brazilian political thought, but also as to the reasons behind this choice. For both him and Guerreiro Ramos, the study of such thought was particularly relevant not because it meant for a contribution to the "progress of the social sciences" (an expression which still held a positivist undertone, of which he was skeptical), but to contribute to the "knowledge of the Brazilian political processes" (Santos, 1970, p. 147). In other words, Brazilian political thought represented a precious source for explanatory hypothesis for all those interested in comprehending the "political contemporaneity" from the perspective of the dynamics of national modernization (the "Brazilian revolution"). Well, "contemporaneity" began with the democratic regime established after the fall of Estado Novo, and therefore corresponds to the period between 1945 and 1965. As for the "Brazilian revolution", it had begun with the 1930 Revolution, and one could expect that the more fertile hypotheses on this process would be produced in the subsequent 15 years (for this reason, Wanderley would dedicate the best of his efforts to examine the Brazilian production during the "Vargas Era", that is, the so called "authoritarian thought"). As for the initial milestone being set at 1870 , it is symptomatic that the Roadmap had adopted the same initial research milestone used by Guerreiro Ramos in 1955 for Efforts in Theorizing the National Reality. Therefore, for Wanderley that would also implicitly be the milestone for the period "predecessor of modern times", which had begun in 1930 (Santos, 1970, p. 147).

\section{Brazilian Sociopolitical Imagination (1967)}

With the objective of critically examining the contempt held by the Brazilian social sciences towards the "history of Brazilian sociopolitical thought", Wanderley Guilherme published his second article on the issue in 1967: The Brazilian Sociopolitical Imagination. In order to characterize the status of his research object, it was not possible at that point 
to bypass or to ignore the dispute that took place during the 1950s between Guerreiro Ramos, in Rio de Janeiro, and Florestan Fernandes, in Sao Paulo, concerning the scientific or pre-scientific nature, respectively, of the Brazilian intellectual production. Between qualifying the intellectual reflection that marked Brazilian political thought as scientific, according to the nationalized perspective on science adopted by Guerreiro, and labeling it as pre-scientific, according to Florestan's universalism, Wanderley preferred to avoid the dilemma by adopting a middle ground. It if seemed unreasonable to him to consider the type of reflection characteristic to Brazilian political thought as "rigorously scientific", it would just the same be misleading to discard them "by a vague, imprecise and therefore unscientific designation of the 'ideological and scientific"' (Santos, 1967, p. 182).

In pursuit of an intermediate category, he resorted to the one of "social imagination". The concept had been coined not long before by Wright Mills in an article in which he sought to call attention to the socio-scientific intuition that guided the work of social agents, such as journalists, educators, and liberal professionals (Mills, 1965, p. 11 e 25). Wanderley then adapted Mills' category to denote the particular political reflection produced in Brazil by those public intellectuals, which according to him expressed the series of intellectual representations on political process disseminated within the national public space since the independence: it was the "Brazilian political imagination". ${ }^{2}$ While acting within the public sphere, this "public-intellectual" was not a social scientist, but neither were they a mere vehicle for commonplace knowledge. The "opinion makers" were people who rationalized political events, interpreting and explaining them to the larger public. Therefore, they converted private opinions into public beliefs. The conflicting evaluations on political issues stemmed primarily from differences in in the opinion makers' personal expertise and personal dispositions, sense of urgency, and the availability of heterogeneous and fragmented data. Besides, the political imagination was linked to both the past and the future. To the past for the reason that multiple previous events were bound into a preliminary rational explanation regarding what had happened; and to the future because the political imagination would delimit the horizon of expectations by which all political actors acted. If everyone would act according to an evaluation of the possible consequences of their acts, their actions would depend of the worldview provided to them by the political

2 "Here, 'political imagination' refers to the type of political evaluation that some men of an educated perception and committed to the public in one form or another are compelled to make. With no time or/and ability to carry out a careful research, these analysts are forced to mobilize all available information in order to offer a rational explanation for their audience. It is natural, therefore, that the final product is an illustrative mixture of economic data, social indicators, cultural traces and political rumors and that the main development sources are political journalists, economics and political leaders" (Santos, 1970, p. 137). 
imagination. This is why it was "the first laboratory where human actions (...) are treated as raw material, processed and transformed into political history" (Santos, 1970, p. 138).

By this point, Wanderley Guilherme was harsh critic of all previous studies which attempted to delimit Brazilian political thought. The analysis criteria hitherto adopted were based on post facto rationalizations - such as the claim that all of Brazil's cultural past was alienated, essayistic and non-scientific; or colonial and non-national. Besides, the interpretive matrices employed - of an institutional and evolutionary nature - was too dependent on temporal accidents. The step-based scheme of a "institutionalization of scientific-social activity" adopted by Florestan in order to assess the scientific or non-scientific nature of an autochthonous sociopolitical work was criticized by Wanderley as being "rudimentary"; considered to be based on an unacceptable historiographical positivism, since it multiplied anachronisms (Santos, 1967, p. 186). Guerreiro Ramos was the only scholar whose work effectively collaborated to the study of the "history of Brazilian sociopolitical thought". Not only did he abandon the premise that the Brazilian cultural production was irrational or arbitrary in regards to the real sociopolitical process, Guerreiro also rejected the formal-positivist criteria dependent on "temporal chronology accidents", preferring instead to classify authors according to the inductive or deductive nature of their analyses and establishing a set of explanatory categories in the dichotomies therein present, therefore investigating the leads left by the author of Sociological Reduction, correcting its eventual deficiencies, excesses and gaps. But, firstly, there was a need to proceed with the "rigorous (bibliographical) survey of the Brazilian cultural past" (Santos, 1967, p. 190).

\section{The Roots of Brazilian Political Imagination (1970)}

The fourth product from Wanderley Guilherme's research was an article titled The Roots of Brazilian Political Imagination and its objective was to identify the prevailing dichotomous explanatory patterns within Brazilian political imagination: "The tendency to represent social life as a continuous struggle between two groups of conflicting phenomena is the most important characteristic in the Brazilian political imagination" (Santos, 1970, p. 137). By considering the political literature in order to encompass the 1964 military movement, Wanderley asserted that regardless of their judgment on the event, the authors had a tendency to explain it from a polarized view concerning causes and phenomena. Mass participation, communism, corruption, administrative disorder, demagogy, governmental inefficiency, all of these were phenomena that, while independent from one another, were presented as a whole by those who argued in favor of the coup d'état. Their opponents, in turn, behaved just the same by placing in a positive spectrum the defense of democracy, industrialization and national independence, and clumping in a negative 
spectrum issues such as imperialism, ruralism, the legislative power and authoritarianism - as if all of these phenomena maintained a connection. Therefore, what defined the explanatory pattern behind the Brazilian political imagination was the analysts' dichotomous perception of the conflict (Santos, 1970, p. 145).

What are the origins, however, of a similar pattern? For Wanderley, the dichotomous explanation resulted in a political culture which provided a "default latent analysis" to the producers of Brazilian political imagination. In other words, there was a historically and culturally established dichotomous explanatory paradigm prior to the 1964 movement. Besides the socialization by basic social values and norms, the political maturation of a community underwent the intellectual conversion of their analysts to certain culturally crystallized perceptions, which were relatively autonomous, both in the places occupied by them within the socioeconomic structure as well as in the empirical daily life of politics. This was the main reason as to why resorting to Brazilian political thought was essential: even if it did not happen to contribute to the "progress of social sciences", its study was indispensable to the "knowledge of Brazilian political processes" (Santos, 1970, p. 147). Therefore, the first and decisive step in this direction was to overcome the scientismist prejudice, primarily diffused by Florestan Fernandes and that impeded "Brazilian intellectual history" to be known and examined beyond institutional accidents ${ }^{3}$.

Naturally, the acknowledgment of a Brazilian political culture carried an embedded risk of attributing a "Brazilian character" or a "national psychology" to Brazilian thought. Wanderley circumvented such risk by calling attention to the historical and "modern" condition of the dichotomous style of political perception, which would have surfaced only by the late 1800s. During the Empire, another type of analysis prevailed, which understood politics as a permanent struggle for power by able and experienced men whose political orientations varied according to the tactical results produced (Santos, 1970, p. 148-149).

By this point, there was a reaffirmation of the criticism towards the previous approaches by other social scientists concerning their institutionalist bias, which resulted in contempt towards Brazilian political thought "for the only reason that it was produced before the founding of schools of Social Sciences". Only 12 articles written in the previous years were dedicated to understanding, organizing and criticizing Brazilian political thought. These were, in chronological order: 1) Fernando de Azevedo, Brazilian Culture - introduction the study of culture on Brazil (1943); 2) Djacir Menezes, La Science Politique au Brésil au cours des trinte dernières années (1950); 3) Costa Pinto and Edson Carneiro, The Social Sciences in Brazil (1955); 4) Guerreiro Ramos, Efforts in Theorizing the Politically Oriented National Reality from 1870 until now (1955); 5) Guerreiro Ramos, The Jeunesse Dorée Ideology (1955); 6) Guerreiro Ramos, The Sociological Subconscious - study on the 1930s Brazilian political crisis (1956); 7) Djacir Menezes, La Sociologie au Brésil (1956); 8) Fernando de Azevedo, The Sciences in Brazil (1956); 9) Florestan Fernandes, Sciences and Society in Brazil's Social Evolution (1956); 10) Florestan Fernandes, Socio-Historical Development in Brazil (1957); 11) Florestan Fernandes, The Pattern of Scientific Works of Brazilian Sociologists (1958); e

12) Guerreiro Ramos, The Ideology of Order (1961). 
The change would have started in the early years of the Republic, with the slow decline of human agency as the raw-material for explanation and its replacement for economic and social issues. For some of the first analysts, there was a need to decide over to potentialities for the country - to be industrial, economically autonomous, independent and sovereign, or a monoculture, economically dependent and colonized. Euclides da Cunha was argued to have been the first great author to establish an "intellectual formula for the political analysis that lay ahead: discovering a dichotomy to which the origin of eventual crises may be rationally attributed; proposing a political alternative for the reduction of the dichotomy". This was the "basic structure of the paradigm" (Santos, 1978a, p. 45), which would be often repeated during the First Republic by studies marked by "contrasts, oppositions and polarizations" (Santos, 1970, p. 150) ${ }^{4}$.

Within this paradigm change process, the 1930 Revolution would have been the watershed moment by generalizing the dichotomous explanatory pattern and, with it, the conviction that the origins of the latent crisis that crossed Brazilian society should be sought in the unfolding of some contradiction (Santos, 1970, p. 152). During the first half of the 1930s, all first line analysts recurred to the dichotomous explanatory pattern, regardless of their ideological positions, whether reformists, conservative or indecisive. After the Estado Novo, the dichotomous approach returned in the articles in the Cadernos do Nosso Tempo journal and in the ISEB's intellectual activity, consolidating itself as a reflexive paradigm where the Brazilian intellectuality of a generation would mature (that is, the 1960 decade). Once the existence of "a long residual historical tradition of political analysis in Brazil" (Santos, 1970, p. 155), was proven, Wanderley Guilherme accentuated the productivity of returning, developing and verifying in Brazilian contemporaneity certain explanatory hypotheses expressed by post-revolutionary authors: "There will hardly be among the contemporary theories a good hypothesis on Brazilian politics that has not already been developed during the 1930s" (Santos, 1970, p. 156).

\section{Paradigm and History: the Bourgeois Order in the Brazilian Social Imagination (1978)}

At the end of the 1970s, Wanderley Guilherme published the two most important articles of his research: Paradigm and History: the bourgeois order in the Brazilian social imagination and Liberal Praxis in Brazil: proposals for reflection and research.

4 In passing, Wanderley argues that the discussion concerning race almost always had the purpose of pointing out to how the "Brazilian type" was constituted and describing the dichotomous historical formation. But this would only hold true for the "serious analysts", something not applied to the second line ones such as Paulo Prado (Santos, 1970, p. 151). 
Paradigm and History: the bourgeois order in the Brazilian social imagination was an inflated consolidation of previous articles by which Wanderley systematized and updated his reflections, introducing new hypotheses and digressions, and, finally, presenting an unprecedented result. In the introduction, Wanderley Guilherme affirmed that - as it had happened everywhere else - the social sciences in Brazil were founded and developed by the combined influence of the accommodation of the knowledge produced in the central countries and the internal stimulus of national history. Since each country and its subsequent culture acquired "national individuality at the same time in which it is integrated in universal history", this would overcome the polarization between science and non-science, universality and particularity (Santos, 1978a, p. 17). The different shades of the social sciences in each country stemmed from how each nationality absorbed and transmitted the foreign production as well as from the interaction between national events and scientific reflection. The process where a national science arose had begun with "Brazil's insertion in universal history", that is, with the discovery of the country; however, he recognized that given the tight connection between the Portuguese State and the Second Scholastic, scientific modernity in our world only dated back to the pombalino period ${ }^{5}$. The proclamation of independence triggered a new period for Brazilian intellectual development, operated by schools of higher education in the Empire and reverberated by the parliamentary and journalistic tribunes. With the foundation of the first superior schools for political, social and economic sciences, the type of sociopolitical reflection produced in Brazil increased its quantitative and qualitative threshold between 1919 and 1935; as for the attempts to reinvent the national social patrimony, there was the reaffirmation of the thesis that the decades of 1920 and 1930 were a privileged moment for our sociopolitical reflection, and whereby the authors of the 1950s and 1960s merely reproduced with more sophistication. The misconception that during this period a "dawn of Brazilian thought" took place and the subsequent indifference to any previous intellectual production was initially attributed to the authoritarian interim of the Estado Novo regime, which would have interrupted the stimulating "efforts in theorizing the national reality" (Santos, 1978a, p. 23), and secondly, to the overvaluation of the impact represented by the foundation of new schools in social sciences, under the direction of foreign professors.

It was with this point that Wanderley Guilherme presented once again his updated and increased critical diagnosis of the "state of the art" in the field of studies on Brazilian

5 This narrative towards Oliveira Martins, which attributed Portugal's cultural backwardness to its jettisoning of modernity by means of the Counter-Reform and the Second Scholastic, apologetic to Pombal's modernizing work was incorporated by Wanderley my means of the "excellent works" by Paulo Mercadante and Antônio Paim, who were at the time dealing with the production of the history of ideas in Brazil through the broad angle of philosophy (Santos, 1978a, p. 59). 
thought. The existing analyses could be grouped according to the criteria employed: institutional, sociological and ideological. The passage concerning the first of those matrices reiterated the passage in The Brazilian Sociopolitical Imagination - with only a few alterations in style - and reproached the previous studies by Costa Pinto, Fernando de Azevedo, Djacir Menezes and Florestan Fernandes for conferring centrality to the emergence of higher learning institutions in the social sciences. The reference to the sociological and ideological matrices however, brought forth an innovation: in an attempt to explain the variations in the concerns of the social investigators, the sociological matrix was considered to be conducted by the socioeconomic structure. These variations could be a consequence of occurring changes in the socioeconomic structure (Florestan Fernandes) or to infer the attributes or dimensions of social thought from the social process (ISEB). As it happens, most of the authors classified in this matrix, such as Edgar Carone, would have settled in describing the aspects of the social picture and exposing the authors' ideas in the assumption that there would be enough evidence of a relation between the two. As for the articles by Florestan regarding the foundation of the social sciences in Brazil, these would have been no more than a series of frustrated attempts from a sociology of knowledge. Even though his analyses were more "stimulating and fertile with suggestions" among those produced by the "sociological matrix", the revered chief in the Paulista sociology had failed by allowing himself to be taken away by the belief that the "mere enunciation and description of the attributes of social processes would be enough evidence to support the functional dependence relation between the content of thought and the unfolding of empirical social history" (Santos, 1978a, p. 28 e 31).

By examining these authors, Wanderley began the second part of the article with a question: was there an appropriate manner for examining these authors who comprised Brazilian political thought in order to do justice to their condition of analysts? And if so, what would it be? At this point he engaged in an interesting methodological interlude by which he argued that there was no given method that could be pointed out as adequate $a$ priori: "There is no such thing as a single history of political and social ideas in Brazil, nor of the social disciplines by the time of their institutionalization, which would allow us to discard all others as false (...). It all depends on the usefulness of the envisaged objective" (Santos, 1978a, p. 57). And here, underlying this argument was the issue of uniqueness or multiplicity of the objects of knowledge. If the investigator assumed that there is a single and real meaning of social phenomena, he should, as Hegel would, conceptually articulate them to their temporal development, disregarding anything that conflicted with it as irrelevant. However, if one believed in the multiplicity of objects of knowledge, the researcher should recognize that any ideas elaborated in a given historical period would produce consequences, many of which are unexpected. It seemed to him that in regards to the social 
sciences, this relativist epistemology was more adequate (Santos, 1978a, p. 34). It would then be possible to investigate the history of ideas with several goals, such as verifying its impact on the perception of the problems; evaluating the most influential intellectual paradigms during a certain period; examining how ideas were deployed to attack or to defend certain political organizations; or to ascertain its effect on the employed methodologies.

Within this field of known possibilities, Wanderley pointed out two possible forms to describe the "evolution of social sciences in Brazil" (that is, the history of Brazilian sociopolitical thought). The first possibility was guided by the patent content in the published works. This guidance was an important novelty. Up until then, Wanderley Guilherme's main concern had been to understand how past analysts (his "predecessors", so to speak) represented the dynamics of Brazilian politics prior to the 1930 Revolution and elevated their conclusions to the condition of a "political science" valid as being "imagination". For this reason, Wanderley's previous articles did not reveal an interest in examining Brazilian thought as a set of proposals or world visions by each author - a hypothesis that would lead to the examination of the patent content in the discursive proposals within their respective historical contexts. Likewise and for the same reason, the research had the initial 1870 threshold, leaving the majority of the monarchic period in the background and regarding it as a "pre-modern" era for Brazilian reflection. Wanderley now sought to fill those blanks, even if partially, throughout the seven pages where he described the development of "Brazilian sociopolitical thought" starting with the independence period and based on themes addressed by the works and relating them to the political agenda of each historical period. The assumption was that different stages in the national construction process demanded certain needs or specific successive tasks from the political class, which would then be reflected in the works produced within an environment of debate. Thus, Viscount of Uruguai and Nabuco stood out in the imperial debate concerning the national State; while Euclides, Romero and Alberto Torres privileged issues pertaining to the social organization during the First Republic.

However, Wanderley persisted with the thesis - even if attenuated - that the first decade of the Vargas Era would have been the par excellence period for Brazilian political thought. It was during those seven years that the agenda for a modern Brazil emerged and, for better or worse, within it was the justification for studying other historical periods. To his judgment, the Isebian merit mostly lay in the fact that they had practically limited themselves to the development of themes privileged by Brazilian thought during the 1930s. By using the patent content of the articles as criteria Wanderley concluded a narrative for the evolution of the social sciences in Brazil, seen as the history of Brazilian political thought and underscoring the successful institutionalization and expansion of homonymous courses, which had taken place in the previous two decades. 
The second possibility of a rational ordinance in the history of this development resided in the description of manners by which social reality appeared to be structured in the analysts' perceptions. Thus followed a somewhat altered reproduction, although with no changes in the general argument concerning the paradigms on the perception of political conflict - the "Machiavellian" and the "dichotomous", outlined in The Roots of Brazilian Political Imagination. If the pages dedicated to the republican period did not display substantial changes when compared to the articles published eight years earlier, the same cannot be said of the treatment given to the authors of imperial period, much more refined than in the previous articles. Even if he reiterated that monarchic thinkers nourished an individualistic vision of political conflict, to Wanderley Guilherme it now seemed that only propagandists such as Ferreira Viana could be reduced to it. There were two more complex groups of authors who flaunted different characteristics. The first group - of which Zacarias and Tavares Bastos were exponents - would analyze Brazilian reality by the prism of already existent doctrines; the second group was more concerned with the effectiveness of those doctrines by means of a "sociological" examination of the country's reality - and here the paradigmatic author was Viscount of Uruguai. This greater sophistication in the classification of imperial authors foreshadowed what is probably the most important part of the article, in which he unprecedentedly inquired about the reasons as to why a tradition or specific political culture was formed in Brazil and which considered reality to be dichotomous (Santos, 1978a, p. 42).

In order to answer his own inquiry, Wanderley brought forth the proposition that in reality all Brazilian political thought (or at least the most valuable and important part) was driven by the need to overcome an authoritarian and fragmented social reality, considered to be backwards for the attainment of an ideal liberal and capitalist (bourgeois) society - in turn considered to be modern. For this reason, analysts tended to present their arguments in a polarized manner: since they joined, on the one hand, what was perceived to be backwards, and on the other hand, what was considered to be modern. Even if the authors agreed as to the objective to be reached, they disagreed as to the more convenient strategies to reach such desideratum. Ever since the empire one could identify the presence of two families or intellectual lineages within Brazilian political thought, which agreed to the ends but diverged as to the means. Conservative politicians and authors (the "saquaremas"), such as Viscount of Uruguai, realized that the State was a privileged agency for social change since it would be the only agent able to establish the conditions for the practical attainment of the dominant preferences and political values: the establishment of a liberal order. Hence the defense for the expansion of the State's regulatory capacity, embodied in a centralized and bureaucratized State, without which privatism, fragmentation and slavery could be not overcome. Such strategy contrasted with the one adopted 
by liberal authors and politicians (the "luzias"), such as Tavares Bastos who argued for decentralization and parliamentarism and were consequently liable to an "institutional fetishism", by believing - in an anti-historical and universalist manner - that the "institutional routine would create the social and political automatisms adjusted to the normal works of a liberal order" (Santos, 1978a, p. 51).

As one could see, by this stage the Empire was no longer a "prehistory" of modern Brazilian political thought and was converted instead in the gestation period for its main division: the different strategies sought by authors in search of a model for political modernity. With effect, resulting from the consecration of the dichotomous style of analysis, the twentieth century's rupture with the previous century revealed itself to be more deceptive than real. By underlining the hiatus between the real country and the legal country and by refusing institutional fetishism and disbelieving the possibility of a liberal order without the State's intervention, the "authoritarian" thinkers of the 1930s emerged as the "true successors" for the Second Reign saquaremas. It was the endurance of an oligarchic and landowning structure that justified the imperative of "continuing the expansion of the regulatory and symbolic capacity of the public power and to further ensure its extractive capacity with the objective of financing the expansion of a modern bourgeois Brazil" (Santos, 1978a, p. 53). Despite their disagreements as to the role of public power as well as other issues, all of them speculated over the most suitable way for Brazil to achieve a liberal order. In the meantime, the national State needed to be strong; and only afterwards could be it be weakened. The thematic as well as the conception of society held by the 1930 authoritarians would reappear in the ISEB production by Guerreiro Ramos and Hélio Jaguaribe, who continued to call for the expansion of the bourgeois order by means of a national-developmentalism. Meanwhile, the Udenists cultivated an institutional fetishism and continued to proceed as the Empire's liberal doctrinaires, demanding a classic liberal institutionalism, which in that context could only benefit oligarchic privatism. However, Wanderley Guilherme underlined that in that moment the situation was undergoing a transformation (1978): the military regime had created a national scale market society and had reduced our backwardness to a residual situation. Because of this, traditional supporters of an instrumental authoritarianism - them too! - had begun to demand for the emergence of classic liberal institutions. This time around the risk was that Brazil would once again fall in the opposite end, with the transition from authoritarianism to a new oligarchic liberal regime, led by a minimal State, captured by private interests, and uninvolved with the tackling of social liabilities. 


\section{The Liberal Praxis in Brazil (1978)}

The second article published as a book chapter was titled The Liberal Praxis in Brazil: proposals for reflection, and it dealt with Brazilian political thought. It was an essay on the ups and downs in establishing a liberal order, understood as "a certain vision as to how society and government could be organized as opposed to a religious control of society and to the establishment of a public property agenda by any power transcendent to society" (Santos, 1978a, p. 68). The article was rooted on the conclusions found in Paradigm and History concerning the near consensus of Brazilian analysts towards the need for a modern liberal society and in their essential divergence as to the means towards such goal. The "liberal praxis" in the article's title therefore referred not only to the attempts carried out in creating this society, but also to the hardships faced amidst this task. The first part of the article is comprised of an interpretation of the events related to the historical process in building a Brazilian liberal order, destined to demonstrate that the adoption of liberal politics many times produced effects opposite to those desired. The argument reads that the liberalism dilemma was firstly and unequivocally expressed by Oliveira Viana: it was not possible for a liberal political system to properly thrive in the context of an authoritative, familial and parental (i.e., anti-liberal) society. In order to promptly reach a democratic order, instead of an institutional based classical liberal system, a certain dose of authoritarianism was deemed necessary to crush the obstacles of its advent, still present in such a backwards society. The full impact of a reading of Brazilian Political Institutions is noticeable on Wanderley Guilherme's interpretation, which led him to later reading of Viscount of Uruguai (an author whose work was not featured in the research's initial bibliographic threshold), thus allowing him to ground the Isebian intellectual tradition in a much more remote past than he initially imagined.

Even though they were described at the end of Paradigm and History, it was only now that the two main traditions of Brazilian political thought would be properly named: doctrinaire liberalism and instrumental authoritarianism (Santos, 1978a, p. 93). Doctrinaire liberals were political actors and their respective associations, who since the $19^{\text {th }}$ century luzias conveyed the belief that "Brazil's political-institutional reform, just like anywhere else, would naturally stem from the formulation and execution of general adequate rules". Led by Rui Barbosa and Assis Brasil, the doctrinaire liberals of the 1920s believed that in order to overcome a situation of backwardness, clientelism and fraud, which marked the Republic, one would need only to eliminate corruption and renew the governing staff by means of wholesome institutional reforms, leading therefore to electoral fairness, an independent judiciary and a professional bureaucracy. However, after the 1930 revolution, it became clear that Getúlio Vargas preferred to trail the path opened by the Tenentist 
movement. Even though they equally aspired for a liberal order, the "instrumental authoritarians" realized that the prescriptions administered by the doctrinaire liberals would not be enough to reach such objective. Getúlio also realized that the reintroduction of a liberal scaffold would re-enthrone the oligarchies which had previously benefited from this situation during the First Republic. After the fall of Estado Novo, the doctrinarian liberals regrouped in the National Democratic Union (UDN), whose agenda was not substantially different to the one of previous decades. The major difference was in the change of tactic: after the second consecutive defeat to the Getulismo representatives in the 1951 presidential elections, the liberals turned towards coupism, a position grounded in an alleged manipulation of an ignorant and needy electorate by the "populist" forces. Within this context, considered by them to be a swindle of the "spirit" of constitutional institutions, the doctrinarian liberals felt comfortable to impede the deepening political degradation and authoritarian populism by means of an open plea to a military coup (Santos, 1978a, p. 99).

As for the other "intellectual family", it was necessary to distinguish between two types of authoritarianism supporters present in Brazilian political thought: the first were ontologically authoritarians, while the second were only instrumentally authoritarians. Among the first we can find, for example, the Integralists, who based their authoritarianism in the natural inequality among men so as to justify the exercise of power in the hands of those more capable. Among them we can also find Azevedo Amaral and Francisco Campos, who believed that although all men were naturally equal, the authoritarian exercise of power had become inevitable in modern times. These authors considered authoritarianism to be a permanent - and not transient - political medication for the Brazilian political order, which pushed them away from "the oldest and most resistant form of authoritarian thinking in Brazil": the instrumental authoritarianism (Santos, 1978a, p. 103). Ever since the country's independence there was the belief that the State should be responsible for "setting the goals for which society should fight for, since society itself was unable to do so, and attempting to maximize national progress" against the forces of backwardness and parochial interests. Being therefore different from the ontologically authoritarians, the instrumental authoritarians also distinguished themselves from the doctrinarian liberals for not believing that social change could derive merely from the establishment of liberal institutions. By believing that "the authoritarian exercise of power, due to its greater potential for reformism, would be the most swift mean to edify liberal society", it then seemed legitimate and adequate for the instrumental authoritarians to leave the State "to expansively regulate and manage social life" (Santos, 1978a, p. 103). The paradigmatic book in this line of thought would be Brazilian Political Institutions by Oliveira Viana. After some considerations on the difficulties faced in Brazil for the accomplishment of the instrumentally authoritarian project, both during Estado Novo 
as well as during the military regime, the conclusion once again underlined - just as the one in Paradigm and History - the need to group together the ideals of political freedom and social justice, which in turn demanded a separation between political liberalism and economic liberalism.

\section{The 1970 Decade and the Controversy Surrounding "Brazilian Au- thoritarian Thought"}

Paradigm and History and The Liberal Praxis in Brazil became classic texts in Brazil and were used in the following decades for studies concerning Brazilian political thought in Masters and $\mathrm{PhD}$ postgraduate programs at the former IUPERJ (currently IESP-UERJ), making their way into other institutions where masters and doctors therein graduated would eventually work. The success in this dissemination of research results, however, does not mean that it was exempt from criticism. These soon evolved into a controversial debate concerning "Brazilian authoritarian thought" circa 1975 - that is, in a period of distension for the military regime.

A first version of Paradim and History was in circulation since at least 1974-1975; therefore, when it was finally published in Bourgeois Order and Political Liberalism three years later it had already suffered several public critiques from Bolívar Lamounier and Hélgio Trindade. The criticism was particularly focused on the article's final section, which interpreted Brazilian thought from a shared "bourgeois paradigm", pursued by both lineages of thinkers (doctrinarian liberal and instrumental authoritarians) essentially divided in their divergence as to what should be the most adequate way to achieve this goal. Lamounier's criticism came in the form of a chapter in the book General History of Brazilian Civilization, which was dedicated to the formation of the so called "Brazilian authoritarian thought" during the First Republic. Accused of being sympathetic to a "instrumental authoritarian" lineage and contrary to political liberalism, Wanderley had supposedly committed the mistake of incorporating "the self-image of authoritarian thought itself towards Oliveira Viana" and the Isebian "nationalist historicism of the 1950s", which associated the "strengthening of public power with development and social progress". According to Lamounier, Brazilian authoritarian thought did not desire a liberal society; it was authoritarian tout court; making for a true "State ideology" which opposed an authentic liberal ideology that had the market, and not the State, as its matrix. According to Lamounier, Wanderley himself belonged to a specific "family" of Brazilian thought: "enlightened authoritarianism" (Lamounier, 1977, p. 382). As for Hélgio Trindade, while he encompassed Lamounier's criticisms, he focused however on defining the Integralist authors (Santos, 1978a, p. 55). In 1976 he published an article in which the attacked the interpretation of 
the so called authoritarian thinkers, considering it to be excessively generalist. Besides, Wanderley allegedly had used out of context excerpts in his thesis in order to reinforce his interpretation of a dissimilarity between integralists and fascists (Trindade, 1976, p. 126-135).

By his own account, Wanderley was preparing to publish a second version of Paradigm and History which would contain his rebuttal to the criticisms coming from Trindade and Lamounier, placing them in a section of the article intended to examine the explanatory matrices used by Brazilian political thought analysts. Differently to the institutional or sociological matrix, the ideological matrix was concerned with approaching Brazilian political thought "with the explicit objective of finding its own conceptual characterization independently from the hazards of empiricism" (Santos, 1978a, p. 31). The first representative author is Guerreiro Ramos; here Wanderley would reproduce a passage from The Brazilian Sociopolitical Imagination which highlighted the pioneer nature of his work and underline the developments introduced by in the field of study. The other authors mentioned as belonging to this matrix were Trindade and Lamounier, criticized for employing analytical categories which erased any trace of ideological differences between the authors. By equating categories such as anti-liberalism, authoritarianism and right-wing radicalism, Trindade's work was arguably marked by a "complete confusion (...) between the concepts of authoritarianism, corporatism, fascism, right-wing, and eventually even of monarchy" (Santos, 1978a, p. 30-31). In turn, besides dissolving the relevant nuances and differences between the authors, Lamounier would have created others of scarce or dubious analytical value. In particular, he criticized the "confusing notion of 'State ideology" created to examine authoritarian thought insofar that it stemmed from the assumption - in itself "ideological" - that the market model dispensed a normative concept of State; these assumptions contradicted "any serious analyses of the relation between the States bureaucratic apparatus and the several existent social groups" (Santos, 1978a, p. 32).

Regardless of the merits or successes of the disputes and rebuttals, the controversy involving the three scholars in the 1970s contributed to consolidate that field of studies. There was an implicit consensus in the discord: at no time did the parties involved question the dignity of a tradition of political thought in Brazil prior to the institutionalization of the social sciences, nor the relevance of its study for the understanding of Brazilian politics. At no time did they recuperate the Hegelian analytical apparatus when examining intellectual-political history, nor did they nourish doubts as to the autonomy of the political in face of the socioeconomic. Old issues were definitely surpassed, which during the 1950s and 1960s haunted the field, concerning mimetism, the originality or authenticity of Brazilian thought, which still persevered under a certain Marxist sociology. This consensus concerning the ground rules of Brazilian political thought research can also found in 
the most important works published during the second half of the 1970s: Evaldo Amaral Vieira, Jarbas Medeiros, Maria Tereza Sadek and Francisco Iglesias. With good reason, by the end of that decade, Bolívar Lamounier could declare himself to be satisfied: "nowadays, Brazilian political thought is a field of studies fully legitimate and fully vaccinated against the virus of ideological schematism" (Lamounier, 1978, p. 11).

\section{Conclusion: a Research Assessment}

The research by Wanderley Guilherme dos Santos was a landmark for Brazilian political thought studies within the social sciences. First of all, it produced a disciplinary framework of the object. Its pragmatic and moderate epistemological perspective allowed to overcome dilemmas until then imposed by resulting oppositions, be it from a philosophical Hegelianism, predominant at ISEB - "critical conscience", "authenticity", "rational thought" versus "naïve conscience", "alienation", "colonial thought" - , or be it from a scientific positivism adopted by the USP sociology during the mid-1950s - by opposing "science' versus "non-science" or "essayism" -, which displayed a contempt for Brazilian thought, considered to be peripheral or inferior. The formation of a national scientific knowledge no longer depended on a bona fide transplant of foreign processes (Florestan) or on a need to found a national social science (Guerreiro). On the other hand, contrary to what was sustained by academic Marxism, Brazilian political thought could not be merely reduced to an ideological expression of the class to which its authors belonged. If there is no doubt that Brazil's peripheral condition reflected itself on the national production, this did not lead to inferior analyses, but instead a dichotomous approach that was adopted by national authors committed to a modernizing ideal, which led them to relate, on the one hand, the causes that competed for the perceived backwardness and, on the other hand, the factors that could surpass this situation. In summary, Wanderley Guilherme's research brought forward the thesis that there was a national political culture; that Brazilian political thought was, par excellence, its intellectual product and that it was impossible to understand the rugged Brazilian political process with studying it.

Secondly, the research brought a clear definition of its statute and its competent given name: the objective was to study "Brazilian sociopolitical thought" and, in particular, the "political imagination" therein present. Even though these expressions may seem interchangeable, the first one is broader than the second. Brazilian Sociopolitical Thought was made up of "articles and books written by Brazilians with the study object geared towards the social or political aspects of Brazilian society" (Santos, 1970, p. 147). As for Political Imagination, it did not refer to sociopolitical thought as a universality of writings, but "to the type of political evaluations that some men with an educated perception and 
committed with the public in one way or another are compelled to make (...) in order to offer a rational explanation for their audiences" (Santos, 1970, p. 137). For Wanderley, what mattered most was "to learn about Brazilian political processes" by means of identifying the "political imagination" diffused in "Brazilian sociopolitical thought". One could criticize the "rushed analysts" classification given by him to the ones responsible for the production of the "Brazilian political imagination"; after all, every political author is also an actor, which by means of his writing attempts to somehow influence the public sphere. But this classification is understandable in a context in which Wanderley Guilherme's primary concern was to give to the "Brazilian political imagination" a dignity that was questioned by Florestan Fernandes' sociology. Hence the expressions "political imagination", "social imagination", and "sociopolitical imagination", employed since the beginning of the controversy so as to oppose the idea of reducing relevant thought to "social science". These were the efforts that contributed to a foundation of a Brazilian political science that did not suffer from the continuity solution that could be seen in the establishment of the Sao Paulo sociology (Lamounier, 1982, p. 407, 409 e 417).

However, the prevailing name to designate the discipline was not "Brazilian political imagination", but "Brazilian sociopolitical thought". This change of preference in the terminology was not a major change within the perspective inaugurated with the term "imagination"; instead, it signaled a moderation in the need to employ that specific term to refer to the analyzed phenomenon. Until the mid-70s articles it was less relevant to determine which term carried more precision to characterize the study object than to criticize the basic "ideology vs. science" duality, which needed to be eliminated so that the dignity and relevance of Brazilian political reflection prior to the establishment of the social sciences could be asserted and, quite possibly, provide their continuity to the reflections produced by opinion makers not dedicated to the scientific study of society, and independently from the results of these sciences. Once the dignity of the object was ensured, Wanderley was unconcerned with further critical elaborations as to what term should baptize the field of study; and so, "Brazilian sociopolitical thought" that began to enjoy a positivity which, during the first articles, seemed to be reserved solely to the "Brazilian political imagination".

Thirdly, the research defined the perimeter for Brazilian political thought within the social sciences. By deliberately excluding from the research "work that was strictly historical, anthropological, psychological, economic, methodological and scholastic" (Santos, 2002, p. 14), Wanderley organized the field of studies of Brazilian political thought. The analyses of Brazilian society only interested Wanderley Guilherme's research insofar as it would lead to the furnace of "political imagination". Beyond the relation of established

6 The evolution of the titles in the works published mirrors his growing desire in specifying 
precedence in the very designation more often employed by him - sociopolitical thought -, this perspective of subordinating the social to the political reveals itself when Wanderley articulates the research's guiding question: "In what way does social reality appear to be structured in the perceptions of the social analysts of the past? And more specifically, how do they see this development within the political dispute? (Santos, 1978a, p. 41). Therefore, by pursuing how politicians and political analysts diagnosed Brazilian society for practical purposes of political intervention, he moved away from the "history of ideas in Brazil", of a broad nature, as were the history of philosophical ideas by Miguel Reale and Cruz Costa, but also from the amorphous "social thought" by Djacir Menezes as well as from the social-literary perspective of Antônio Cândido. Therefore, it was no longer even a "Brazilian social thought", understood as being the history of Brazilian culture, nor a "Brazilian social and political thought", understood as a set of analyses on politics and society. From that we can safely affirm that his research is constitutive of the field of studies on Brazilian political thought within the sphere of the social sciences ${ }^{7}$.

In fourth place, Wanderley Guilherme's research considered the characterization of Brazilian political thought to be inseparable from practice. The active and pragmatic character of such "imagination" provided "schemes" of rational explanation which gave order and made legible the heterogonous data used by the political analyst. If imagination necessarily works from the ordination of what already took place, it establishes a horizon of possibilities in which any political action may be conceived and take place. In this sense, the product of its creation directly falls on the present context, guiding and rationally legitimizing the actions of its actors (Santos, 1970, p. 138). It is this very decisive pragmatic element, which in The Roots of Brazilian Political Imagination is subjacent to the concept of "praxis" and would later serve for an analysis of Brazilian liberalism in Bourgeois Order and Political Liberalism. Even though the notion is vague, the pragmatic element is unmistakable (Santos, 1978a, p. 67). The few alterations in the second edition of the article Liberal Praxis in Brazil, twenty years later, did not alter the main formulation concerning how "ideas translate into behavior - and political ideas as strategic guides for action"

the research object as being essentially political: In Controversies, the object was designed as "Brazilian social thought"; in Imagination it changed to "sociopolitical imagination"; in Roots of Imagination it was merely "Brazilian political imagination". It is true that in Paradigm and History the expressions "social imagination", "social and political thought", "sociopolitical thought" and "social thought" were used interchangeably. However, this occurred in this article for a punctual and contingent reason: by consolidating and expanding the previous articles, the essay also attempted to trace an "evolution of the social sciences in Brazil" and not only of political science. Also present in this article, the eventual returns by the author to the expression "social" should not therefore fool us.

7 This founding characteristic of the research is recognized even by his critics, such as Bolívar Lamounier (1982, p. 430) and Gildo Marçal Brandão (2007, p.25). 
(Santos, 1998, p. 9). In this sense, what remains is the conviction that, contrary to sociological or philosophical theory, political theory is always linked to practice and for this reason its study cannot eliminate $a$ priori the pretext of its non-scientific or ideological dimension.

This examination of Wanderley Guilherme's research cannot be concluded without touching on the largest controversy of his research: the instrumental label conferred to a portion of Brazilian authoritarian thought. In a time when Iberian and Latin-American political scientists discussed the authoritarianism issue with the background attempt to discuss the deepening of democracy in their countries it was a true provocation to qualify an author such as Oliveira Viana as a liberal in values and goals. Without a doubt, a great deal of the controversy that followed is due to the fact that there was no clarity or safety as to the meaning of the terms "bourgeois order" and especially "authoritarianism" in his last articles. Be it as it may, it is often forgotten that in his interpretation of Oliveira Viana, Wanderley Guilherme based himself exclusively on the reading of Brazilian Political Institutions - a work that does not deal with the issue of capitalism nor the market and that does not advocate for any regime of exception. In this framework, as long as the concept of "bourgeois order" is understood as equivalent to a State of a democratic rule of law the "Authoritarian State" considered in the sense that Oliveira Viana himself uses in that work - of a modern State, interventionist and, as such, geared towards social wellbeing and the safeguarding of civil rights -, his qualification of an instrumental authoritarianism remains pertinent. Otherwise, Wanderley does not merely praise Oliveira Viana and criticizes him once again ${ }^{8}$.

Regarding the consequences of this controversy, the boldness in praising Oliveira Viana, at a time when his books could be found bedside to some of the most important heroes of the military regime, exposed Wanderley Guilherme to being attacked from both the left and the right as being sympathetic to authoritarianism; for both sides he was considered to have merely incorporated - in Bolívar Lamounier's expression - the "self-image of Brazilian authoritarian thought". However, in sight of an attentive reading of his articles, the provocation seems to lack foundation. The first and most evident resides in the fact that these articles often contain criticism towards authoritarianism, for both Estado Novo and the military regime (Santos, 1978a, p. 39). Besides, contrary to what is often believed, at no point did Wanderley present the Estado Novo and the military regime as materializations of "instrumental authoritarian" thought. Instead, what is argued is that

8 Wanderley criticizes Oliveira Viana for his belief in the advent of an untraceable governing patriotic elite, which would change Brazilian political culture, and for his inability to grasp the transformative meaning behind urbanization and industrialization, as experienced by Brazil since the 1930s, preferring instead to consider the Country, even late in life, as being essentially rural (Santos, 1998, p. 49). 
those experiences, for being purely authoritarian, would have been frustrated opportunities to implement such an ideal. And more: even the João Goulart administration was pictured as a futile attempt at instrumental authoritarianism. This meant that: firstly, the instrumental mentality was not exclusive to the right, and could also be encompassed by the left; secondly, that instrumental authoritarians suffered as much as doctrinarian liberals with the vicissitudes of political reality. The problematic in "liberal praxis in Brazil", however, was not merely about the revealed inability by doctrinarian liberals to establish a bourgeois order by importing liberal instructions, but also of the inability shown by instrumental authoritarians to materialized an institutional and political order that would not be purely authoritarian (Santos, 1998, p. 49-51).

The apparent sympathy towards instrumental authoritarians by Wanderley Guilherme can also be attributed to two further - and less controversial - factors. Firstly, the analyses throughout history carried out by the instrumental authoritarian "lineage" seemed to him to be qualitatively superior to those done by doctrinarian liberals. Besides noticing that the same institutions did not always produce the same effects universally, due to changes in culture and development stage of political communities, the instrumentals believed that the establishment of order could not occur spontaneously by mere force of the social game, a belief shared by the liberal doctrinarian liberals. For the instrumentals, the social world was maintained by an orchestrated political action (Santos, 1978a, p. 49-51). That is, his worldview was at the same time more "political" and more "realist" that his rivals; consequently, he was closer to an ideal of political science harbored by Wanderley. Secondly, in a universe lacking a democratic and national liberalism, the instrumentals were almost always the social carriers for progressive values, with which the author identified himself. Throughout Brazilian history, the saquaremas statesmen, the Tenenetist movement leaderships in the 1920 and 30s, and the national-developmentist intellectuals of the 1950s and 60s seemed to him to have better represented the national interest and the democratic cause than liberal graduates, always attached to state oligarchies, adverse to social equality and supporters of free trade. This sympathy by Wanderley Guilherme towards values advocated by instrumental authoritarians does not however imply in a reduction of the author to their condition, but instead to recognize that for the historian of political ideas there is no foul in recognizing the progressive dimension of such movements, actors or even political regimes, which, in spite of being authoritarian, seem to him to have contributed, in certain historical contexts for the progress of the national cause.

In summary, while he was producing his research in Brazilian political thought, Wanderley Guilherme was not charmed by the instrumental authoritarian agenda, instead, he was concerned with shattering the dilemma between oligarchic liberal order and 
progressive authoritarianism in which Brazil's political history seemed to be imprisoned, by differentiating political and economic liberalism in order to condemn an authoritarian State without condemning an interventionist State (indispensable for reducing the country's social indifference). When the military regime was in a strain, Wanderley alerted to the danger of replacing a military nationalist and interventionist authoritarianism by an atomistic and oligarchic liberalism, a desire shared by a portion of the regime's opposition, which according to him had a "UDN-ish" mentality, being true "conservative wolves transfigured in progressive lambs". Future democratic institutions should not be designed according to the doctrinarian liberal costume or by the instrumental authoritarian costume (at that point argued by him to have disappeared through exhaustion). The imposition was that from a dictatorship a democratic liberal State would be born, and one that would not be minimal; a State sufficiently robust to architect public policies capable of raising the population's living standards to "higher grounds than collective wellbeing" (Santos, 1978b, p. 80). Evidently this was not an instrumentally authoritarian position; it was a social-democratic stance: "The conversion of an authoritarian system into a stable democratic regime depends on the existence of a strong and democratic socialist party, capable of competing on the right against parties which, in name of human liberties wish to maintain alive as much as possible an unjust economic and social order; and able of competing on the left against parties which, in name of social justice, consider the democratic issue to be one for fools or madmen. Socialist and democratic parties tend to convert in the political center of history" (Santos, 1978b, p. 16-17). Not only does his analytical interpretation on Brazilian political thought appear to remain current; the same holds true to the subjacent ideological program.

Translated by Paulo Scarpa

Submitted in July 2013

Accepted in September 2013

\section{References}

BRANDAO, Gildo Marçal. (2007), Linhagens do pensamento político brasileiro. São Paulo: Hucitec.

9 At the same time in which he was writing Paradigm and History and The liberal Praxis in Brazil (1974), Wanderley emphasized in newspaper articles on the early Geisel administration's political conjuncture, the need to "uphold the defense of civil and minority rights without necessarily claiming for a society where the market mechanism is the exclusive resource allocator and distributor of goods (...). The incidence of authoritarian systems in the contemporary world poses the challenge of reconciling civil liberties with the limitations of an exclusively predatory privatism" (Santos, 1978b, p. 35-36). 
LAMOUNIER, Bolívar. (1977), Formação de um pensamento político autoritário na Primeira República: uma interpretação. In: FAUSTO, B., História Geral da Civilização Brasileira. Tomo III, O Brasil Republicano, $2^{\circ}$ Vol., cap. 10. São Paulo: Difel.

LAMOUNIER, Bolívar. (1978), Prefácio. In: SADEK, M. T. Machiavel, Machiavéis: a tragédia octaviana. São Paulo: Símbolo.

LAMOUNIER, Bolívar. (1982), A Ciência Política no Brasil: roteiro para um balanço crítico. In: LAMOUNIER, B. A Ciência Política nos Anos 80. Brasília: UnB.

MILLS, Wright C. (1965), A Imaginação Sociológica. Tradução de Waltensir Dutra. Rio de Janeiro: Zahar Editores.

MOREIRA, Marcelo Sevaybricker. (2008), O diálogo crítico com a teoria poliárquica no pensamento político de Wanderley Guilherme dos Santos. Dissertação em Ciência Política . Belo Horizonte: UFMG.

RAMOS, Alberto Guerreiro. (1962), A Crise do Poder no Brasil. Rio de Janeiro: Jorge Zahar.

SANTOS, Wanderley Guilherme dos. (1965), Preliminares de uma controvérsia metodológica. Revista Civilização Brasileira, vol. 5, no 6, pp. 53-81.

SANTOS, Wanderley Guilherme dos. (1967), A imaginação político-social brasileira. Dados Revista de Ciências Sociais, vol. 2, n 3, pp. 182-193.

SANTOS, Wanderley Guilherme dos. (1970), Raízes da imaginação política brasileira. Dados Revista de Ciências Sociais, nº7, pp. 137-161.

SANTOS, Wanderley Guilherme dos. (1978a), Ordem burguesa e liberalismo político. São Paulo: Duas Cidades.

SANTOS, Wanderley Guilherme dos. (1978b), Poder e Política: crônica do autoritarismo brasileiro. Rio de Janeiro: Forense Universitária.

SANTOS, Wanderley Guilherme dos. (1998), Décadas de Espanto e uma Apologia Democrática. Rio de Janeiro: Rocco.

SANTOS, Wanderley Guilherme dos. (2002), Roteiro bibliográfico do Pensamento Político-Social Brasileiro (1870-1965). Belo Horizonte: Ed. UFMG; Rio de Janeiro: Casa de Oswaldo Cruz.

TRINDADE, Hélgio. (1976), Texto e Contexto: nota crítica a alguns aspectos do estudo paradigma e história de Wanderley Guilherme dos Santos. Revista do IFCH, Porto Alegre, vol. 4, pp. 126-135. 